BARD Research Project US-3999-07

\title{
Simultaneous Treatment of Odorants and Pathogens Emitted from Confined Animal Feeding Operations (CAFOs) by Advanced Oxidation Technologies
}

(A one year feasibility study)

\section{US team}

Jacek Koziel, Jeffery Zimmerman, Steven Hoff

(In collaboration with William Jenks and Hans van Leeuwen)

Iowa State University

Israeli team:

Yael Laor, Uzi Ravid

Agricultural Research Organization, Newe Ya'ar Research Center

\section{Robert Armon}

Technion - Faculty of Civil \& Environmental Eng.

\section{Executive Summary}

A feasibility study was conducted, aiming to explore the potential effectiveness of $\mathrm{UV} / \mathrm{TiO}_{2} / \mathrm{O}_{3}$ photooxidation technologies for simultaneous treatment of odorant and pathogen emissions from livestock and poultry operations. Several key parameters were tested in laboratory (US) and semi-pilot (Israel) scale conditions including: the effects of light energy dose (treatment time and light intensity), relative humidity and air temperature, UV wavelength, presence of photocatalyst $\left(\mathrm{TiO}_{2}\right)$ and the presence of ozone. Removal and conversion of odor, target gases (sulfur-containing volatile organic compounds S-VOCs, volatile fatty acids (VFAs), phenolics, and ammonia), and airborne pathogens was tested. Up to $100 \%$ removal (below method detection level) of S-VOCs, VFAs, and phenolics, the overall odor, and up to $64.5 \%$ of ammonia was achieved with optimized treatment. Treatments involving deep UV band $(185 \mathrm{~nm})$ and photocatalyst $\left(\mathrm{TiO}_{2}\right)$ were more efficient in removal/conversion of odorous gases and odor. The estimate of the operational cost of treatment was based on measured emissions of several odorous VOCs from full scale, commercial swine 
farm ranges from $\$ 0.15$ to $\$ 0.59$ per finisher pig. This figure represents significantly lower cost compared with the cost of biofiltration or air scrubbing.

\section{Introduction}

A feasibility study was proposed for the research year 2007, aiming to explore the potential effectiveness of $\mathrm{UV} / \mathrm{TiO}_{2} / \mathrm{O}_{3}$ photooxidation technologies for simultaneous treatment of odorant and pathogen emissions from livestock and poultry operations. Limited number of previous studies showed the feasibility of advanced gas-phase oxidation technologies to treat odorous gases such as $\mathrm{S}$ - and $\mathrm{N}$-compounds and phenol derivatives. Similarly, still relatively little is known about inactivation of airborne bacterial/viral pathogens with advanced oxidation. Consequently, only a few studies explored the application of theses technologies to CAFO emissions.

The main hypothesis of this research was that advanced oxidation processes $\underline{\text { (UV/TiO }} 2$ /ozone) can eventually be applied simultaneously to treat odorants and pathogens emitted from CAFOs. In this feasibility project we completed research experiments designed to address the hypothesis. We followed the logic of criteria defined in the proposal that would, at the completion of this work, indicate the feasibility of such treatment approach and would then justify a continuation of this study.

\section{Work description}

\section{US - Iowa State University}

\section{Methodology}

Chemicals and standard gases. A standard gas generation system was used to generate 9 odorous VOCs (mercaptans, volatile fatty acids and phenolics) \& $\mathrm{H}_{2} \mathrm{~S}$. $\mathrm{NH}_{3}$ was from EPA-grade standard cylinder. Gases emitted from swine manure were generated by purging manure with air. All gases were delivered to a flow-through photoreactor (Yang et al., 2007).

Photoreactor and UV light sources. A flow-through reaction chamber was designed and built for simultaneous destruction of VOCs and pathogens (Fig. 1). The effects of several variables on the VOC removals, including treatment time, UV light energy dose, relative humidity $(\mathrm{RH})$, temperature $(\mathrm{T})$, initial VOCs concentration, gas flow rate, presence of $\mathrm{TiO}_{2}$, light wavelength and the presence of other gases, were tested using this system. 

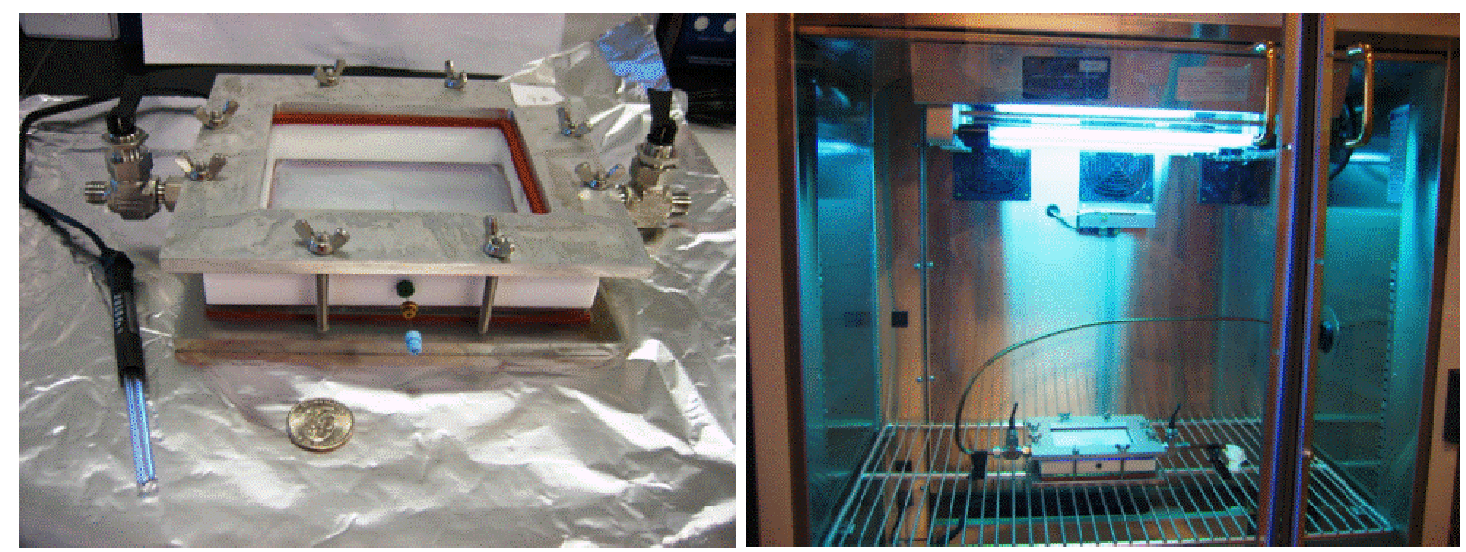

Figure 1. Schematic of photoreaction chamber (left) and $\mathrm{T} / \mathrm{RH}$ control chamber (right) with UV lamps for controlled irradiations of odorous gases.

Two types of 10W UV mercury lamps (American UV Co., Lebanon, IN, USA), were used in parallel, i.e., lamps have principal outputs at $254 \mathrm{~nm}$ (plus other characteristic bands at 312 and $365 \mathrm{~nm}$, respectively) and 'deep' UV lamps with $185 \mathrm{~nm}$ band was also used. The photoreactor temperature was controlled at $25^{\circ} \mathrm{C}$ for all the experiments in this work.

Catalyst preparation. Thin films of Degussa P25 TiO 2 (Degussa, Germany) consisting of $75 \%$ anatase and $25 \%$ rutile and the BET surface area of $\sim 50 \mathrm{~m}^{2} / \mathrm{g}$ powder was used as coating inside the photoreactor (Yang et al., 2007, Yang et al., 2008).

Analytical methods. All gas sampling was performed with solid-phase microextraction (SPME) except for $\mathrm{NH}_{3}$ which was measured with colorimetric method. Gas samples were analyzed on a multidimensional GC-MS-O system and forced-choice olfactometer (Cai et al, 2006; Lo et al, 2008). Odor concentrations were measured at the Olfactometry Laboratory at Iowa State University. Odor was accessed by a forced-choice, dynamic-dilution olfactometer at a total odor basis with four panelists assessing odor detector threshold (ODT) from air samples collected in a 10 liters Tedlar bags.

Procedures. Effectiveness of treatment was assessed as percent removal for each target compound or odor, and was calculated as follows:

$$
\% R=\frac{(\text { Control }- \text { Treatment })}{\text { Control }} * 100 \%
$$


where $\% \mathrm{R}=$ percent removal (or percent conversion); Control and Treatment $=$ measured odor concentrations or peak areas measured with MS detector for target gases for the untreated and treated gas, respectively.

Pathogens. The removal of pathogens was assessed in a static system described in Fig. 2.
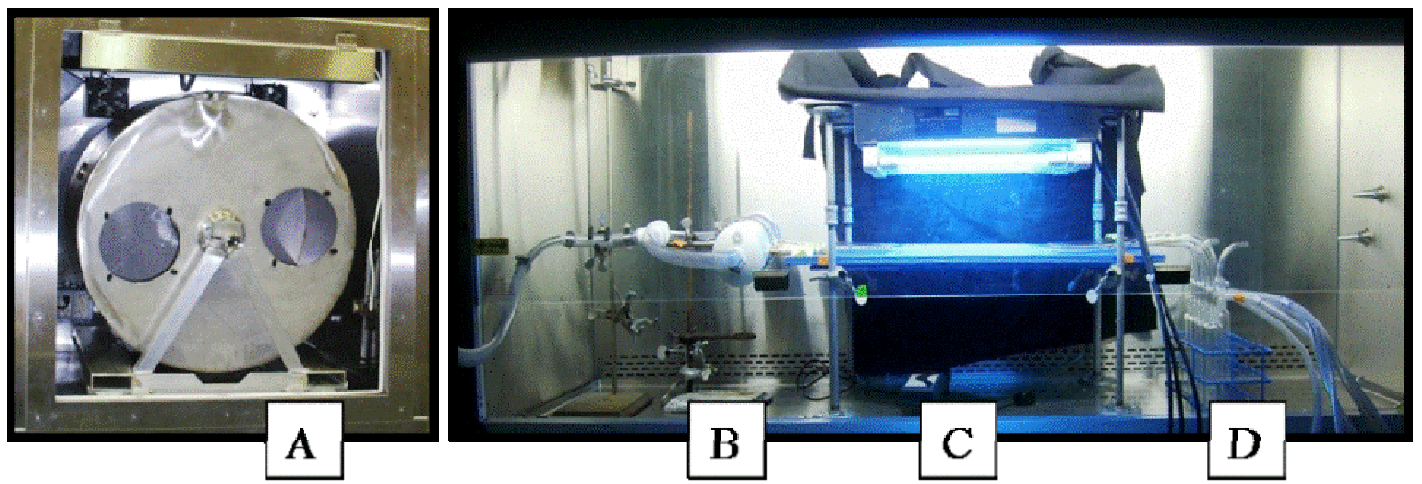

Figure 2. Dynamic aerosol toroid [A] for holding virus aerosols housed in an environmental chamber capable holding a range of temperatures $\left(10^{\circ} \mathrm{F}\right.$ to $90^{\circ} \mathrm{F}$; $\left.12.2-32.2^{\circ} \mathrm{C}\right)$ and relative humidities $(10 \%$ to $90 \%)$. Aerosolized virus is drawn into a manifold [B], passed across of field of UV exposure [C], collected in samplers (impingers) [D], and assayed for infectious virus. Sections [B, C, D] are housed in a biosafety cabinet (NuAire ${ }^{\circledR}$ Series 33 Class II Type B2).

\section{Results}

The results obtained for removal of 9 VOVs (synthetic gas mixture) are summarized in Table 1 and Fig. 3-5. The results obtained for real manure odors are summarized in Table 2.

Table 1. $\mathrm{UV}_{185+254}+\mathrm{TiO}_{2}$ : summary of measured gas concentrations in UV-treated gas and percent reduction $(\mathrm{MDL}=$ method detection limit).

\begin{tabular}{|c|c|c|c|c|c|c|c|c|c|c|c|}
\hline \multirow{4}{*}{$\begin{array}{l}\text { Compound } \\
\text { name }\end{array}$} & \multicolumn{10}{|c|}{ Treatment time (sec) / energy dose at 254nm (J) } & \multirow{4}{*}{$\begin{array}{c}\text { Removal }^{\mathrm{C}} \\
(\mathbf{n g} / \mathbf{J})\end{array}$} \\
\hline & \multirow{2}{*}{\multicolumn{2}{|c|}{\begin{tabular}{|c|}
$2.5 \mathrm{sec}$ \\
$0.02 \mathrm{~J}$ \\
\end{tabular}}} & \multirow{2}{*}{\multicolumn{2}{|c|}{\begin{tabular}{|c|}
$19 \mathrm{sec}$ \\
$2.90 \mathrm{~J}$
\end{tabular}}} & \multirow{2}{*}{\multicolumn{2}{|c|}{$\begin{array}{c}37 \mathrm{sec} \\
5.64 \mathrm{~J}\end{array}$}} & \multirow{2}{*}{\multicolumn{2}{|c|}{$\begin{array}{l}56 \mathrm{sec} \\
8.54 \mathrm{~J}\end{array}$}} & \multirow{2}{*}{\multicolumn{2}{|c|}{$\frac{112 \mathrm{sec}}{17.1 \mathrm{~J}}$}} & \\
\hline & & & & & & & & & & & \\
\hline & $\mathrm{C}_{\text {gas }}{ }^{\mathrm{a}}$ & $\begin{array}{c}R^{b} \\
(\%)\end{array}$ & $\mathbf{C}_{\text {gas }}$ & \begin{tabular}{|c|}
$R$ \\
$(\%)$
\end{tabular} & $\mathbf{C}_{\text {gas }}$ & $\begin{array}{c}R \\
(\%)\end{array}$ & $\mathbf{C}_{\text {gas }}$ & $\begin{array}{c}\mathrm{R} \\
(\%)\end{array}$ & $\mathbf{C}_{\text {gas }}$ & $\begin{array}{c}\mathrm{R} \\
(\%)\end{array}$ & \\
\hline $\begin{array}{l}\text { Methyl } \\
\text { Mercaptan }\end{array}$ & 0.755 & 22.1 & 0.297 & 70.9 & 0.308 & 78.8 & 0.151 & 98.0 & MDL & 99.8 & 4.72 \\
\hline $\begin{array}{l}\text { Ethyl } \\
\text { Mercaptan }\end{array}$ & 1.55 & 25.2 & 0.853 & 66.0 & 0.899 & 73.2 & 0.563 & 97.9 & MDL & 99.7 & 14.6 \\
\hline $\begin{array}{l}\text { Dimethyl } \\
\text { Sulfide }\end{array}$ & 0.428 & 23.5 & 0.267 & 63.6 & 0.273 & 67.4 & 0.187 & 92.2 & MDL & 99.6 & 4.94 \\
\hline Butyl & 0.224 & 29.3 & 0.112 & 65.8 & 0.121 & 75.3 & 0.073 & 94.5 & MDL & 99.5 & 8.68 \\
\hline
\end{tabular}




\begin{tabular}{|l|c|c|c|c|c|c|c|c|c|c|c|}
\hline Mercaptan & & & & & & & & & & & \\
\hline Acetic Acid & 0.554 & -16.0 & 0.227 & 51.4 & 0.212 & 61.2 & 0.113 & 80.1 & 0.071 & 93.1 & 11.6 \\
\hline Propanoic Acid & 0.456 & 7.16 & 0.198 & 59.9 & 0.185 & 65.7 & 0.084 & 85.0 & 0.042 & 96.7 & 8.65 \\
\hline Butyric Acid & 0.543 & 19.8 & 0.210 & 56.7 & 0.280 & 63.1 & 0.114 & 83.8 & 0.074 & 97.1 & 15.7 \\
\hline Isovaleric Acid & 1.90 & 21.1 & 0.563 & 51.7 & 1.07 & 57.3 & 0.287 & 80.2 & 0.133 & 97.8 & 49.2 \\
\hline p-Cresol & 3.00 & 25.4 & 0.637 & 64.6 & 1.11 & 72.8 & 0.143 & 91.7 & 0.019 & 99.9 & 78.9 \\
\hline
\end{tabular}

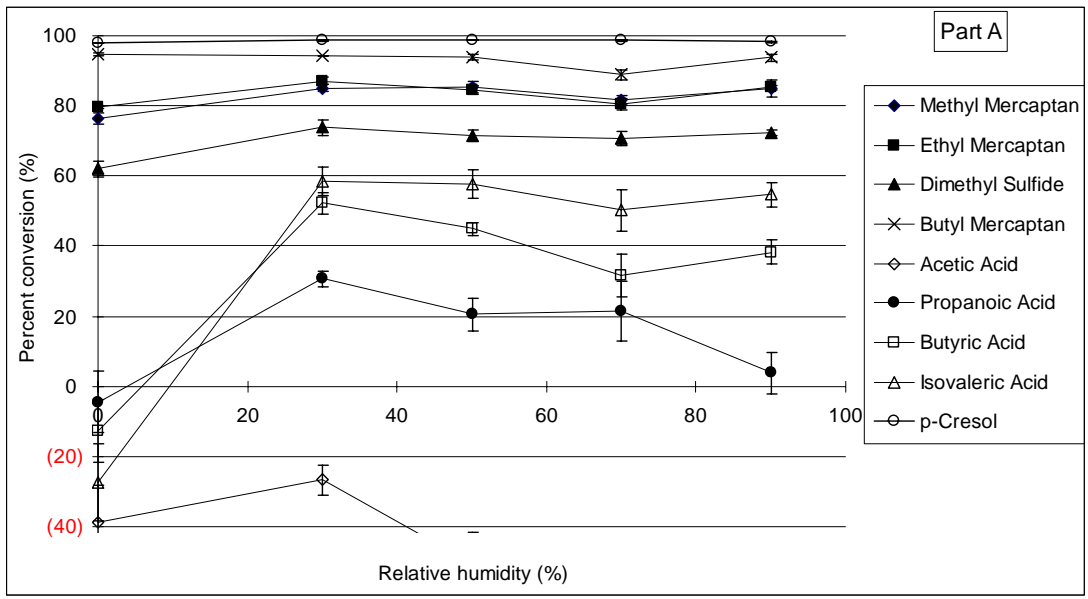

Figure 3. $\mathrm{UV}_{185+254}+\mathrm{TiO}_{2}$ : effect of relative humidity (\%) on percent conversion of target odorous VOCs. Experimental conditions: light intensity at $254 \mathrm{~nm}, 312 \mathrm{~nm}$ and $365 \mathrm{~nm}$ is $1.5,0.230$ and $0.084 \mathrm{~mW} / \mathrm{cm}^{2}$, respectively; $25 \mathrm{mg} \mathrm{TiO}{ }_{2} ; 400 \mathrm{~mL} / \mathrm{min}$ airflow; treatment time $=28 \mathrm{sec}$; Carboxen/PDMS $85 \mu \mathrm{m} ; 5$ min sampling time; $\mathrm{T}=25$ ${ }^{\circ} \mathrm{C}$.

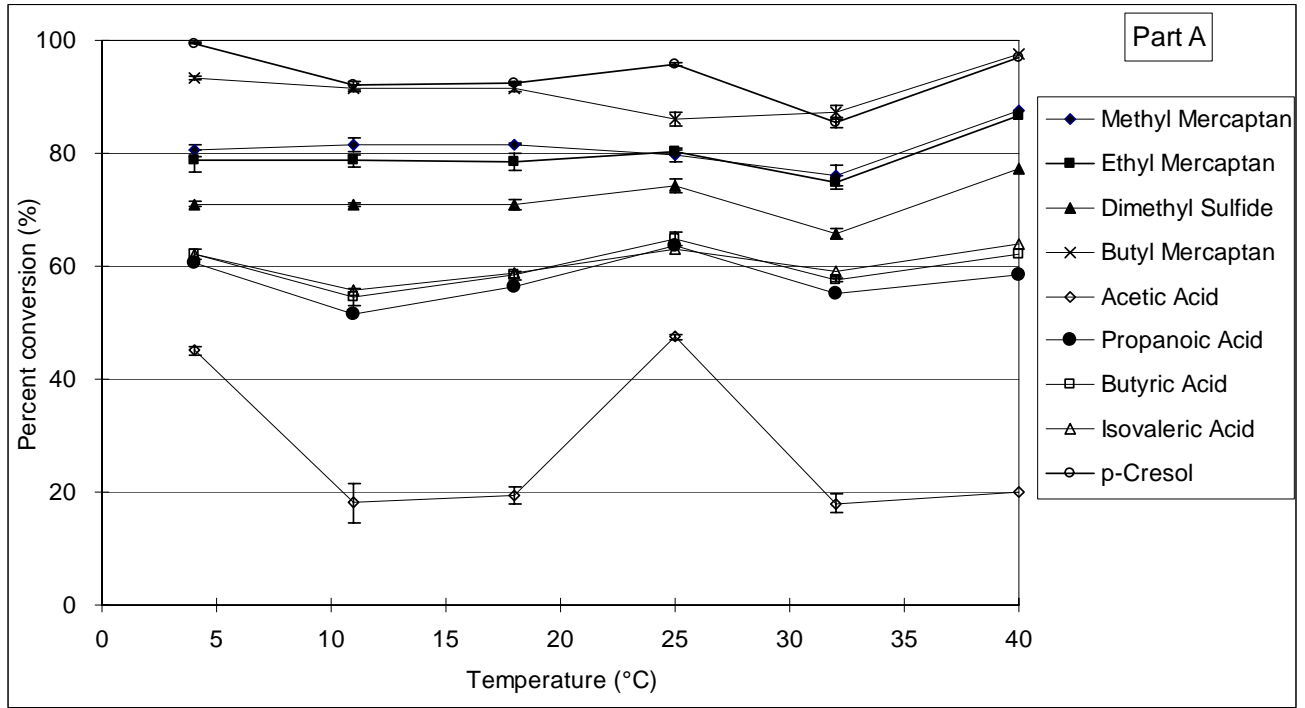

Figure 4. $\mathrm{UV}_{185+254}+\mathrm{TiO}_{2}$ : effect of temperature $\left({ }^{\circ} \mathbf{C}\right)$ on percent conversion of target odorous VOCs. Experimental conditions: light intensity at $254 \mathrm{~nm}, 312 \mathrm{~nm}$ and $365 \mathrm{~nm}$ is $1.5,0.230$ and $0.084 \mathrm{~mW} / \mathrm{cm}^{2}$, respectively; $25 \mathrm{mg} \mathrm{TiO}{ }_{2} ; 400 \mathrm{~mL} / \mathrm{min}$ airflow; treatment time $=28 \mathrm{sec}$; Carboxen $/$ PDMS $85 \mu \mathrm{m} ; 5$ min sampling time; $\mathrm{RH}=30 \%$. 


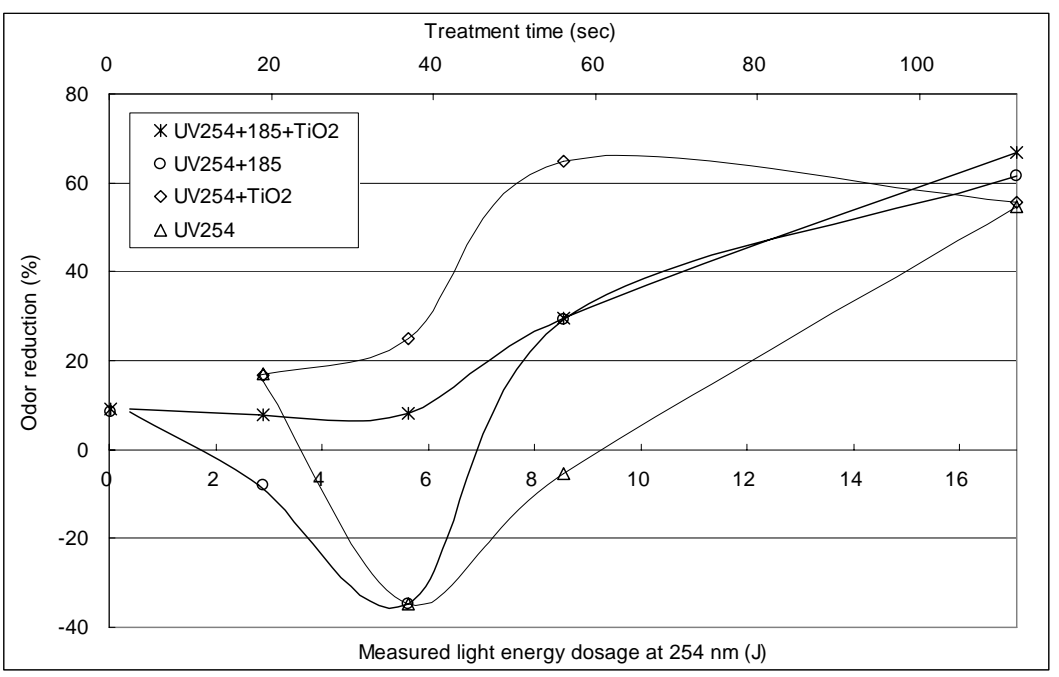

Figure 5. Effect of treatment time on total odor reduction. Total odor reduction (expressed as ODT) as a function of measured light energy dosage at $254 \mathrm{~nm}$ (treatment time). The ODT of each gas sample was assessed by $\geq 4$ trained panelists using a forced-choice dynamic-dilution olfactometer at Iowa State University.

Table 2. Percent reduction (\%) of MS detector response (peak area counts) of selected odorous VOCs emitted from fresh manure with UV treatment.

\begin{tabular}{|l|l|l|c|c|}
\hline \multirow{2}{*}{ RT (min) } & \multirow{2}{*}{ Compound name } & \multirow{2}{*}{ CAS \# } & \multicolumn{2}{|c|}{ Percent reduction (\%) } \\
\cline { 4 - 5 } & & & $\mathbf{U V}_{\mathbf{1 8 5 + 2 5 4}} \mathbf{T i O}_{\mathbf{2}}$ & $\mathbf{U V}_{\mathbf{1 8 5}+\mathbf{2 5 4}}$ \\
\hline 8.48 & Dimethyl disulfide & $624-92-0$ & $\mathrm{MDL}^{*}$ & MDL \\
\hline 16.50 & Acetic acid & $64-19-7$ & -1723 & -2928 \\
\hline 19.5 & Butyric acid & $107-92-6$ & 30.1 & -22.1 \\
\hline 20.18 & Isovaleric Acid & $503-74-2$ & 26.2 & 20.3 \\
\hline 23.01 & Hexanoic acid & $142-62-1$ & MDL & 18.8 \\
\hline 25.50 & Phenol & $108-95-2$ & 94.7 & 67.6 \\
\hline 26.60 & p-Cresol & $106-44-5$ & MDL & 79.3 \\
\hline
\end{tabular}

*Note: MDL is method detection limit, which means the peak area is beyond the detection limit. Therefore the percent reduction is about $100 \%$.

Ammonia abatement -proof-of-the concept experiment. Table 3 summarizes the results obtained for ammonia removal. Highest removal (up to 65.1\%) was obtained using $\mathrm{UV}_{185+254}+\mathrm{TiO}_{2}$ treatment. 
Table 3. Percent reduction (\%) in ammonia concentration (ppm) by different treatment processes under different conditions.

\begin{tabular}{|l|c|c|c|c|}
\hline \multirow{2}{*}{ Treatment processes } & \multicolumn{2}{|c|}{ With VOCs } & \multicolumn{2}{c|}{ Without VOCs } \\
\cline { 2 - 5 } & Dry air & Humid air & Dry air & Humid air \\
\hline $\mathrm{UV}_{185+254}+\mathrm{TiO}_{2}$ & 38.6 & 65.1 & 58.7 & 54.5 \\
\hline $\mathrm{UV}_{185+254}$ & 23.7 & 18.1 & 13.5 & 17.2 \\
\hline $\mathrm{UV}_{254}+\mathrm{TiO}_{2}$ & 34.2 & 34.9 & 44.4 & 43.4 \\
\hline $\mathrm{UV}_{254}$ & 5.26 & 2.41 & 2.38 & 0.00 \\
\hline
\end{tabular}

Experimental conditions: $400 \mathrm{~mL} / \mathrm{min}$ airflow; UV treatment time $=28 \mathrm{sec}$; original ammonia concentration $=50 \mathrm{ppm} ; \mathrm{RH}=60 \%$ for humid air conditions.

\section{Estimation of the $U V_{254}$ inactivation rate (k-value) of viral pathogens}

Inactivation rates (k-value) were determined for 4 viral pathogens swine influenza virus, bovine viral diarrhea virus, PRRSV, and reovirus.

This work was conducted under "static" conditions (virus in liquid medium) using "off-the-shelf" UV hardware from commercial manufacturers (American Ultraviolet

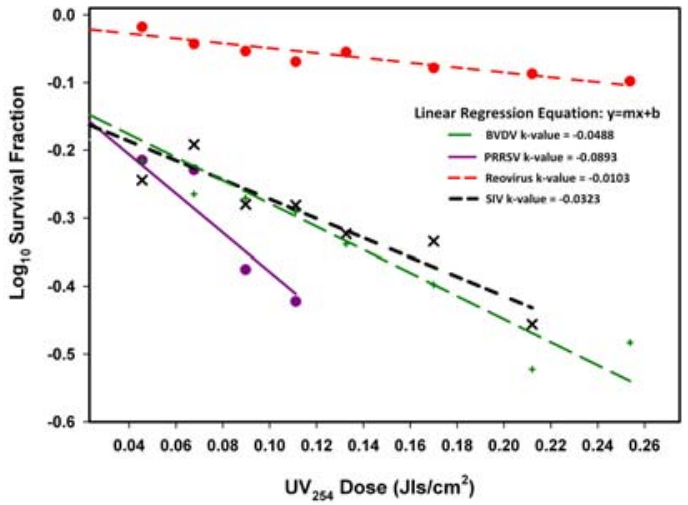

Figure 6. Inactivation rate of 4 viral pathogens. The slope of the line reflects the pathogen's susceptibility to UV irradiation. Co., Lebanon IN).

Fig. 6 showed that SIV, BVDV (used as a surrogate for CSFV), and PRRSV are highly susceptible to $\mathrm{UV}_{254}$ inactivation. Reovirus, a virus resistant to $\mathrm{UV}_{254}$ inactivation, was only included for comparison. The data suggest that UV could be a practical and cost-effective method to inactivate important airborne pathogens of swine.

\section{$\underline{\text { Israel - Agricultural Research Organization \& Technion }}$}

\section{Methodology}

Odor/VOCs source. Purged manure suspension served as the VOCs/odor source. Forty liters of fresh manure suspensions was prepared as follows: Four liters of air dry chicken manure (fattening poultry; Ramat David) were mixed with 40 liters of tap water and stirred manually in a bucket. Large particles were then removed by using 1 mm plastic mesh and the rest of the suspension was transferred into the 200 liters tank 
of the flow-through setup. A fresh suspension was prepared every several weeks such that the VOC/odor source varied from one experiment to another.

Photoreactor. (Fig. 7) A quartz tube (2.5 liters; 2" diameter) was surrounded by a ring of "black light" lamps (18W Philips TLD 18W/08; emission from 340 to $400 \mathrm{~nm}$, with a peak at $365 \mathrm{~nm}$ ) which can be individually controlled. An aqueous $\mathrm{TiO}_{2}$ suspension (2\%; Sachtleben, Germany) was used to coat a round brush (the suspension was sprayed on the brush and dried using a hair dryer) which was placed inside the reactor (Fig. 7e, d). Oil-free compressed air was used to purge the manure and flow through the system. Sampling ports were installed before and after the reactor and included the adjustments for SPME (VOCs), Kitagawa color tubes (ammonia and ozone), and Tedlar bags (odor) (Fig. 8). Odor was collected in 60 liters Tedlar bags and analyzed in the newly established olfactometry lab in Newe Ya'ar (Fig. 9). The effects of flow rate (retention time) and the number of lamps in use (energy dose) were tested using this system. The system was operated outside, at ambient summer temperatures $\left(33-35^{\circ} \mathrm{C}\right)$. The reactor itself was heated from the UV lamps during operation such that the air temperature at the exit of the reactor was several degrees higher than ambient temperature. The relative humidity $(\mathrm{RH})$ of the flowing air (purged through manure suspension) was near $100 \%$.

Analytical methods. All gas sampling was performed with solid-phase microextraction (SPME; DVB/CAR/PDMS from Supelco; Laor et al, 2008) except for $\mathrm{NH}_{3}$ and ozone which were measured with Kitagawa color tubes. Gas samples were analyzed on a GC-MS system. Odor concentrations were measured at the Olfactometry Laboratory at Newe Ya'ar. Odor was accessed by a forced-choice, dynamic-dilution, with six panelists assessing odor detector threshold (ODT) from air samples collected in a $60 \mathrm{~L}$ Tedlar bags.

Procedures. Effectiveness of treatment was assessed as percent removal for each target compound (as explained for the US part) based on peak area counts obtained for separate VOCs or concentrations of ammonia obtained by Kitagawa color tube. 

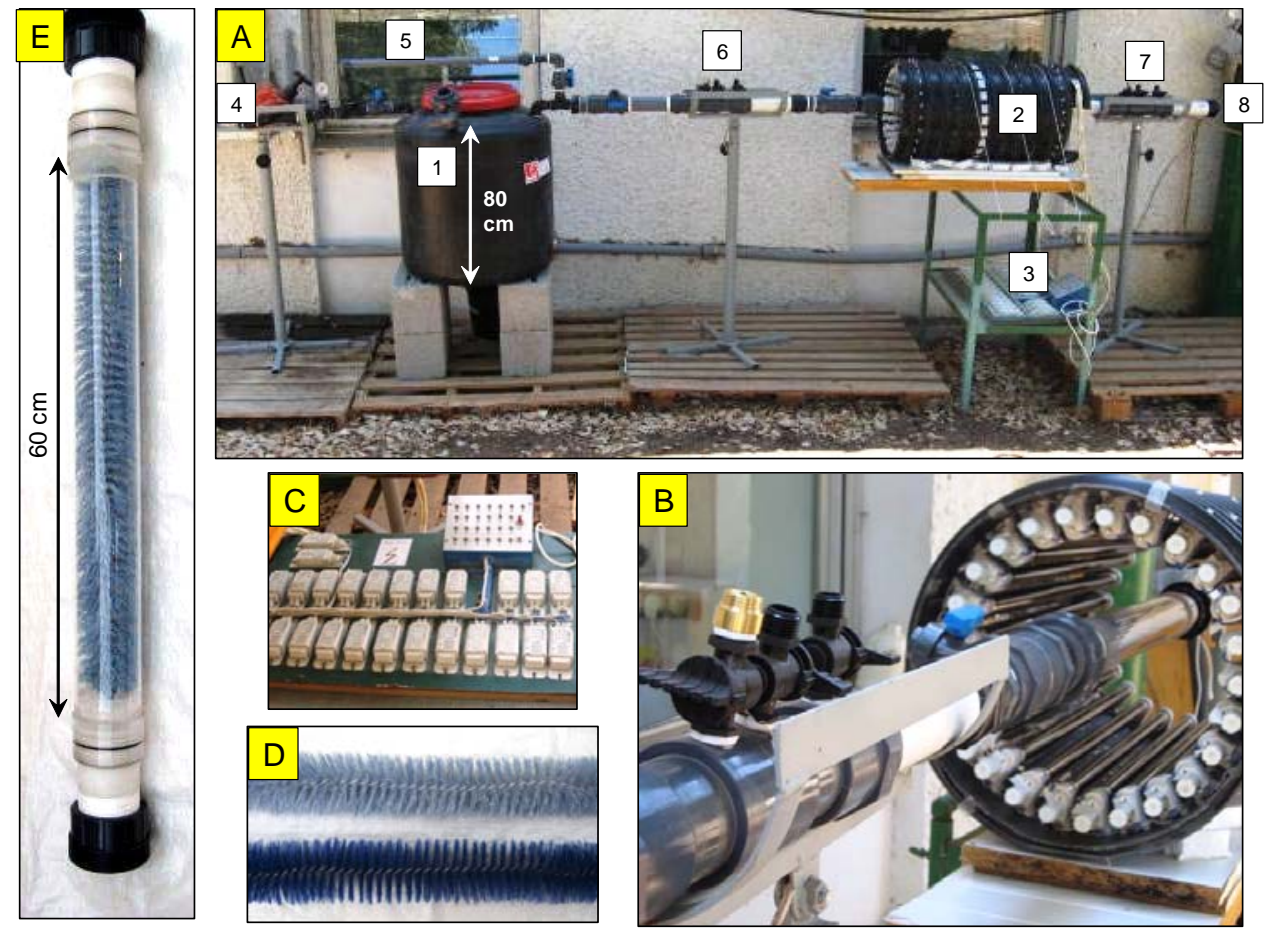

Figure 7. A. The whole setup: 1. A 200 liters tank containing 40 liters of poultry manure suspension. 2. Lamps cover. 3. Electricity board. 4. Compressed oil-free air. 5. Manure bypass. 6. Sampling ports (before treatment). 7. Sampling ports (after treatment). B. Reactor and UV lamps (X24). C. Electricity board (controls individually each lamp). D. Un-coated (bottom) and $\mathrm{TiO}_{2}$-coated (upper) brush. E. A quartz reactor with $\mathrm{TiO}_{2}$-coated brush.
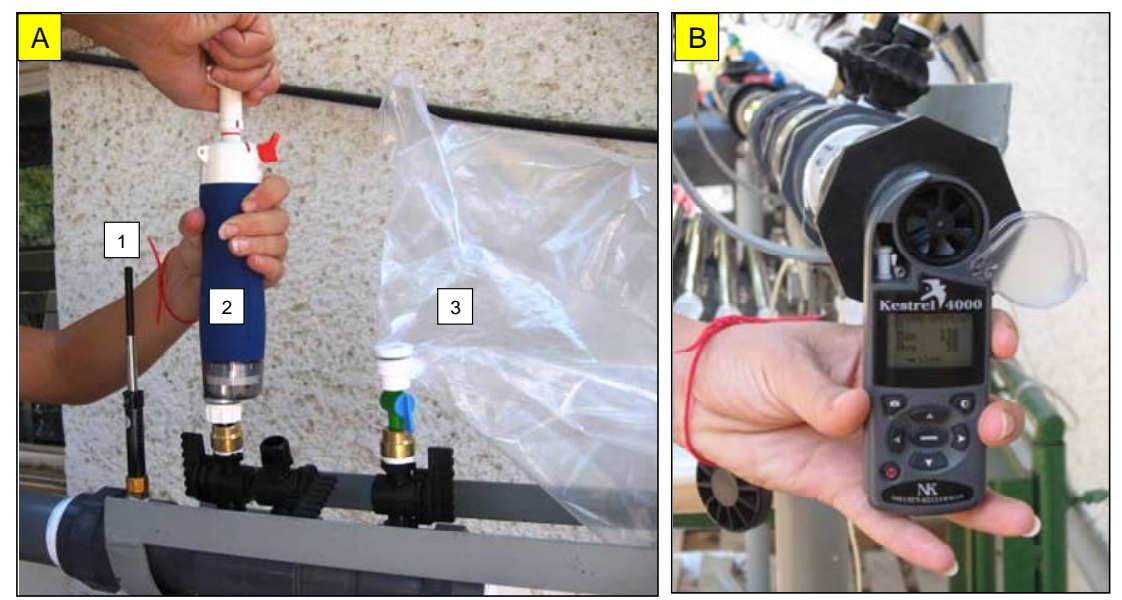

Figure 8. A. Sampling ports before and after treatment: 1. Collecting VOC with SPME. 2. Measuering ammonia or ozone, using Kitagawa pump and color tubes. 3. Collecting odor samples in 60 liters Tedlar bags. B. Measuring linear flow velocity at the setup exit, using Kerstel annenometer. 

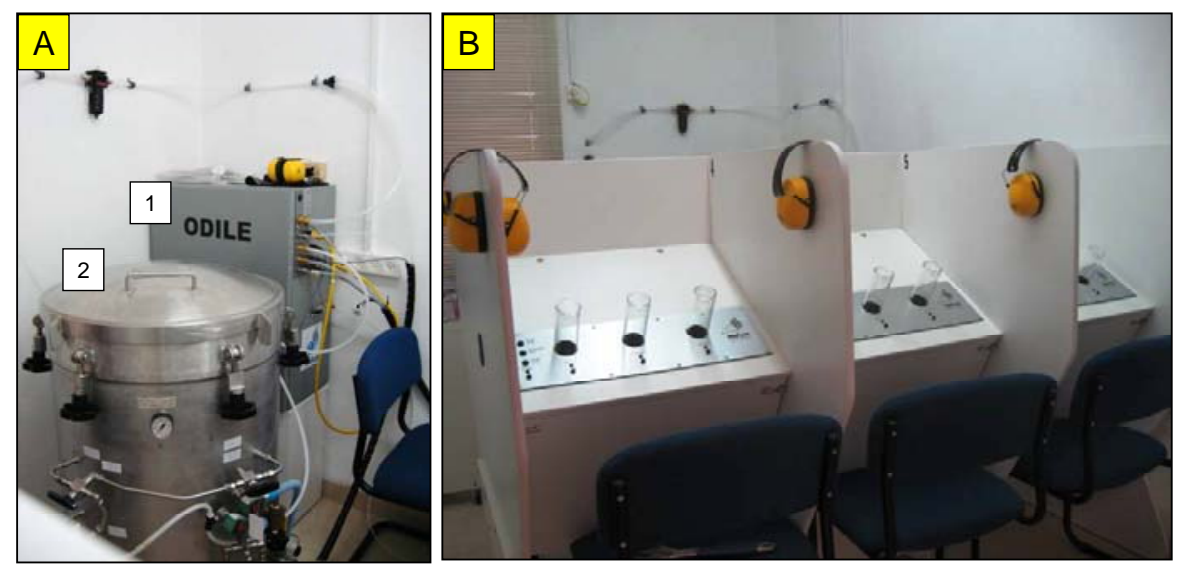

Figure 9. The olfactometry lab in Newe Ya'ar. A. 1. Main dilution unit. 2. Pressurized vessel (in which the Tedlar bags are placed). B. Six-sniffing positions, each contains three sniffing ports for triangular choice odor analyses.

\section{Results}

Removal of selected VOCs at varying flow rates. VOCs removal was tested at flow rates between 24.2-85.1 1/min, which was equivalent to residence time of 1.8-6.3 sec (all 24 lamps were in use). Fig. 10 represents the results obtained for 7 characteristic VOCs, showing $\sim 80-100 \%$ removal for all compounds at residence time of at least $\sim 5$ sec. Dimethyl trisulfide (DMTS) and dimethyl disulfide (DMDS), two key malodor compounds were efficiently removed at residence time of $\sim 2 \mathrm{sec}$. The results obtained for acetic acid (not shown) were not consistent and varied from positive (i.e. removal) to negative (production?) values, independently on residence time.

\section{Removal of selected VOCs using different light intensity (number of lamps in use).} VOCs removal was tested using 4, 8, or 24 lamps (flow rate was between 24.2-27.3 $1 / \mathrm{min}$, i.e. retention time of 5.6-6.3 sec). Fig. 11 represents the results obtained for five characteristic VOCs, showing that DMTS and DMDS, two key malodor compounds were efficiently removed also when 4 lamps were in use. This smaller number of lamps resulted in energy input similar to those applied at higher flow rates and 24 lamps (Fig. 10). 


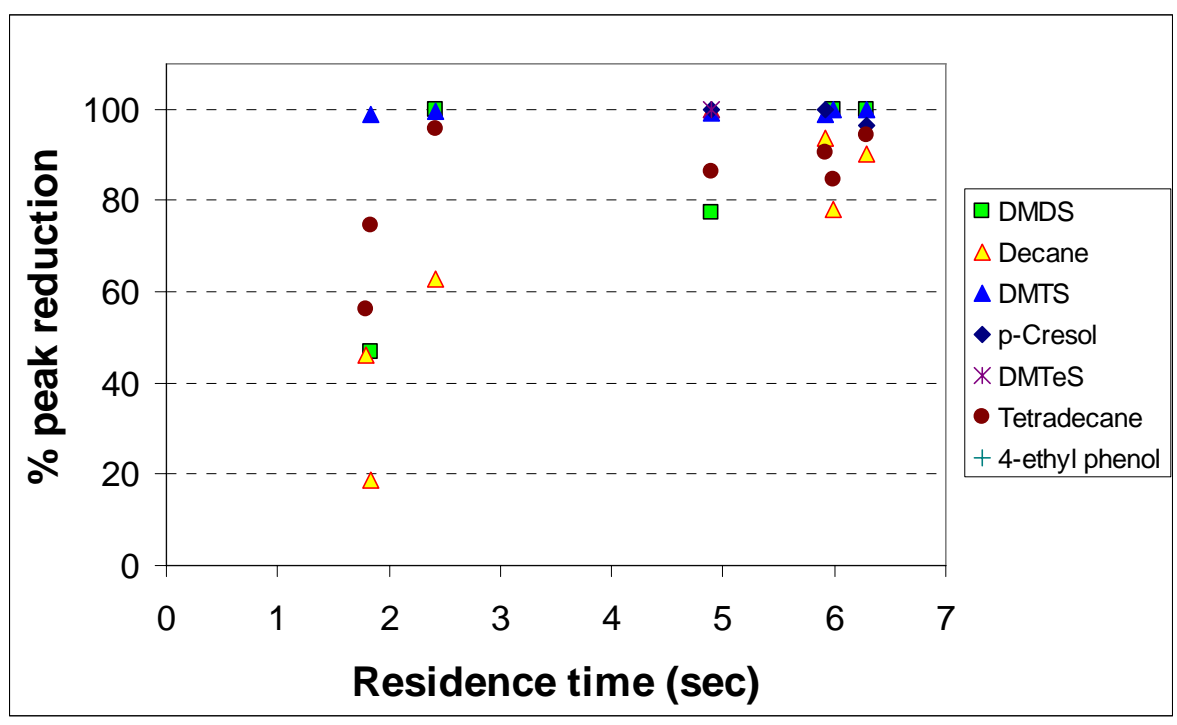

Figure 10. Effect of residence time $(\mathrm{sec}) . \%$ reduction represents the reduction in peak area obtained by SPME-GC-MS (extraction time: $30 \mathrm{~min}$ ). If peaks reduced below detection they were considered as 1000 area counts for reduction calculations.

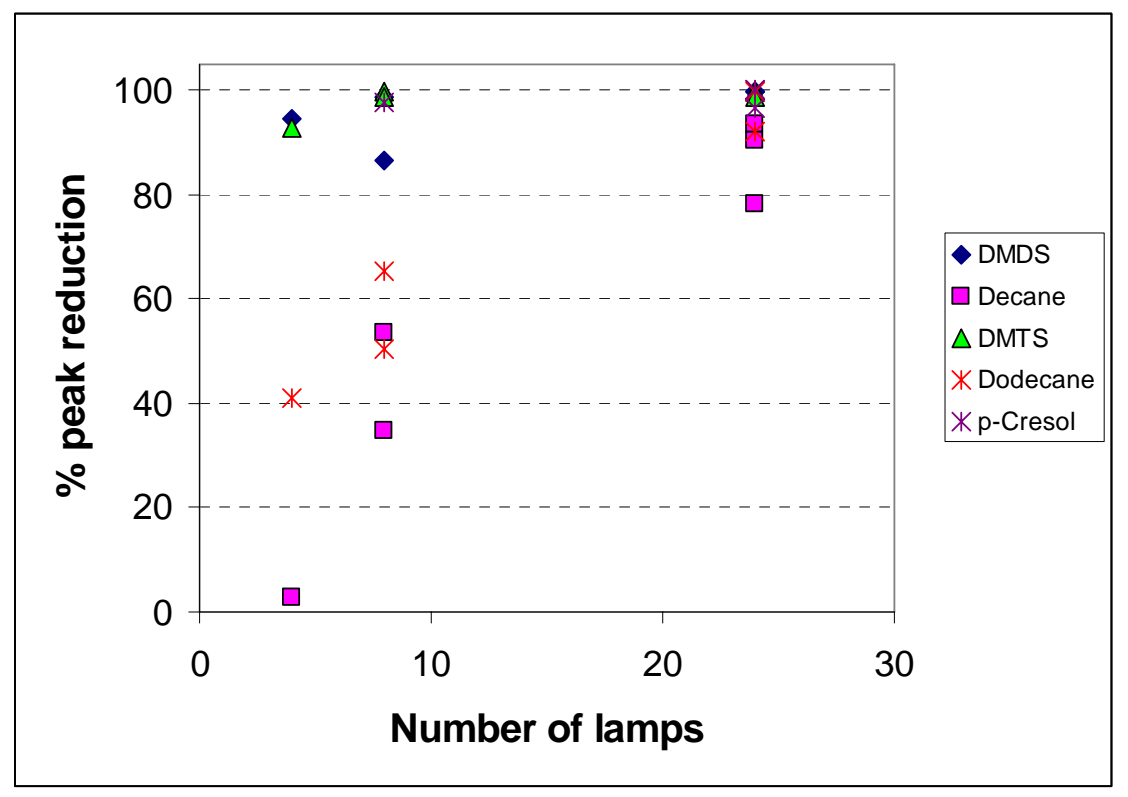

Figure 11. Effect of light energy (number of lamps in use). \% reduction represents the reduction in peak area obtained by SPME-GC-MS (extraction time: $30 \mathrm{~min}$ ). If peaks reduced below detection they were considered as 1000 area counts for reduction calculations.

Ammonia removal. Ammonia was measured with Kitagawa color tubes designed to work for a range of 5-260 ppm. Measured concentrations (different manure suspensions, fresh and aged) varied from several ppm and up to $130 \mathrm{ppm}$. Ammonia removal was not consistent and varied from no removal and up to $\sim 50 \%$ removal. 
Role of Ozone. Ozone measurements were performed with Kitagawa color tubes designed to work with a range of 0.025-3 ppm. Ozone was not introduced intentionally into the system and the first "sign" for its presence was the typical "swimming pool odor" perceived by the operator at the exit of the reactor. Ozone measurements were performed with and without the presence of the $\mathrm{TiO}_{2}$ catalyst (coated or uncoated brush was placed inside the reactor). When uncoated brush was used, no ozone was detected before and after UV treatment. Under these conditions (no catalyst) VOCs were not removed as well. When $\mathrm{TiO}_{2}$-coated brush was placed inside the reactor, ozone concentrations were zero (below detection) before treatment and in the range of 1-2 ppm after treatment. Since some of the ozone presumably reacted with the VOCs this ozone is considered "residual". Auch levels of residual ozone which is produced under $\mathrm{UV}_{365}-\mathrm{TiO}_{2}$ treatment would need to be treated before released into the environment.

Total odor removal. Total odor reduction was analyzed only twice (the lab was recently established in Newe Ya'ar). One experiment included the removal of VOCs from relatively fresh and strongly smelling manure suspension (residence time $=5$ sec; all 24 lamps were in use). Odor was reduced by 75\% based on the EN13725 standard (from 70,296 to 17,234 dilution threshold; DT), or by $77 \%$, based on the ASTM standard (from 60,312 to 13,615 DT). In another experiment done with aged manure which emitted much weaker odors (residence time 5.9 sec; all 24 lamps were in use), the total odor remained basically the same (from 684 to 641 DT; based on the ASTM standard). Yet, the odor character changed substantially from "sewage type" odor to "ozone odor". It seems that at lower odor emissions the smell associated with residual ozone has more impact on total odor measurements. Ozone residuals may be removed after treatment by an ozone destruction unit for health as well as odor concerns. Notably, the above odor measurements are considered preliminary since at the time of measurements (soon after lab establishment) not all panelists were officially certified.

\section{Summary (US and Israel):}

Odor and target VOCs responsible for livestock odor are mitigated either by UV-185 $\mathrm{nm}$ ('deep' UV) in presence of $\mathrm{TiO}_{2}$ as a catalyst or UV-360 nm- $\mathrm{TiO}_{2}$-ozone, into less odorous or odorless products such as $\mathrm{CO}_{2}$ and $\mathrm{H}_{2} \mathrm{O}$. Percent removals from 80 to $99 \%$ 
were measured in lab-scale and semi-pilot scale experiments involving synthetic or real livestock VOCs mixtures. Selected VOCs simulating livestock odor included $p$ cresol, sulfur-containing VOCs, and volatile fatty acids. Treatment cost of $\$ 0.25$ per pig and continuous operation during growing cycle was estimated when the lab-scale results were extrapolated to typical ventilation rates and electricity cost at a swine finish operation in rural Iowa. The long-term goal is to develop cost-effective technology for the simultaneous treatment of odor and pathogens in livestock housing through logical progression of testing from lab-scale, through pilot-scale and finally at commercial scale. Such treatment would be applicable to both the inflow (for airborne pathogen control) and outflow air (for odor and pathogen control) at typical existing and new mechanically-ventilated barns.

\section{Publications from this research:}

1. Koziel, J.A, X. Yang, S. Zhang, L. Cai, S. J. Hoff, H. J. Leeuwen, T. Cutler, J. Zimmerman, W. S. Jenks, Y. Laor, U. Ravid, R. Armon. 2008. Treatment of livestock odor and pathogens with ultraviolet photocatalysis. In the proceedings of The 3rd IWA Odour and VOCs Conference, Barcelona, Spain, October 2008.

2. Yang, X., J.A. Koziel, T. Cutler, S. Zhang, J. Zimmerman, S.J. Hoff, W. Jenks, J (Hans) van Leeuwen, J. Harmon, C. Faulhaber, Y. Laor, U. Ravid, R. Armon. 2008. Treatment of livestock odor and pathogens with ultraviolet light. ASABE Paper \# 085198. ASABE Annual International Meeting. Providence, RI, June, 2008.

3. Koziel, J.A., X. Yang, T. Cutler, S. Zhang, J. Zimmerman, S. J. Hoff, W. Jenks, Y. Laor, U. Ravid, R. Armon, J.H. van Leeuwen. 2008. Mitigation of odor and pathogens from CAFAs with $\mathrm{UV} / \mathrm{TiO}_{2}$ : exploring cost effectiveness. In the proceedings of the Mitigating Air Emissions from Animal Feeding Operations Conference. Des Moines, IA, May, 2008.

4. Yang, Y., J.A. Koziel, L. Cai, S. Hoff, J. Harmon, J.H. van Leeuwen, W.S. Jenks, J. Zimmerman, T. Cutler. 2007. Novel treatment of odor and VOCs using UV photolysis. ASABE paper \# 074139. ASABE Annual International Meeting. Minneapolis, MN, June, 2007.

5. Koziel, J.A., X. Yang, T. Cutler, S. Zhang, J. Zimmerman, S. Hoff, W.S. Jenks, J.H. van Leeuwen, Y. Laor, U. Ravid, R. Armon. 2008. Treatment of livestock odor and pathogens with ultraviolet photocatalysis. Abstract OP-575 In the 
proceedings of the AgEng 2008 International Conference on Agricultural Engineering and Industry Exhibition, Hersonissos, Greece, June, 2008.

6. Koziel, J.A., J. Zimmerman, S. Hoff, H. van Leeuwen, W. Jenks. Research Brief: Simultaneous treatment of odor, VOCs, $\mathrm{H}_{2} \mathrm{~S}, \mathrm{NH}_{3}$, and pathogens with UV light. 2008 Annual Report of the S-1032: Improving the Sustainability of Livestock and Poultry Production in the United States.

\section{Literature cited}

Cai, L.; Koziel, J.A.; Lo, Y-C.; Hoff, S.J. Characterization of volatile organic compounds and odorants associated with swine barn particulate matter using solidphase microextraction and gas chromatography- mass spectrometry-olfactometry; J. Chrom. A 2006, 1102, 60-72.

Laor, Y.*, Koziel, J.A., Cai, L., Ravid, U. 2008. Chemical-sensory characterization of dairy manure odor using headspace solid phase microextraction and multidimensional gas chromatography - $\neg$ mass spectrometry - olfactometry. Journal of the Air \& Waste Management Association, 58(9), Special Issue, 1187-1197.

Lo, Y.C.; Koziel, J.A.; Cai, L.; Hoff, S.J.; Jenks, W.S.; Xin, H. Chemical and sensory characterization of volatile organic compounds and semi-volatile organic compounds emitted from swine manure using solid phase microextraction and multidimensional gas chromatography- mass spectrometry-olfactometry system; J. Environ. Qual. 2008, $37,521-534$.

Yang, Y., J.A. Koziel, L. Cai, S. Hoff, J. Harmon, J.H. van Leeuwen, W.S. Jenks, J. Zimmerman, T. Cutler. 2007. Novel treatment of odor and VOCs using UV photolysis. ASABE paper \# 074139. ASABE Annual International Meeting. Minneapolis, MN, June, 2007.

Yang, X., J.A. Koziel, T. Cutler, S. Zhang, J. Zimmerman, S.J. Hoff, W. Jenks, J (Hans) van Leeuwen, J. Harmon, C. Faulhaber, Y. Laor, U. Ravid, R. Armon. 2008. Treatment of livestock odor and pathogens with ultraviolet light. ASABE Paper \# 085198. ASABE Annual International Meeting. Providence, RI, June, 2008. 